\title{
IMPERADOR ATÉ MORRER: ANTROPOLOGIA DOS CICLOS TEMPORAIS DE UMA ESCOLA DE SAMBA EM PORTO ALEGRE/RS
}

Liliane S. Guterres

Este artigo tem por objetivo discutir as representações de tempo observadas entre um grupo de pessoas que trazem em comum sua ligação com o carnaval de Porto Alegre/RS.

A antropologia há muito está preocupada com a questão das diferentes noções de tempo existentes entre as culturas. Da Matta (1983) aponta para, pelo menos, duas concepções clássicas; a uma representação do tempo linear, histórico - presente na ideologia ocidental dominante -, contrapõe-se uma outra forma de reconhecer, representar e viver a experiência temporal, percebendo-a dentro de uma cronologia cíclica.

Para pensar as diferentes representações temporais no mundo, trago dados de campo da pesquisa de mestrado em uma Escola de Samba, uma etnografia do Grupo Carnavalesco Imperadores do Samba ${ }^{1}$. Percebe-se que inúmeros participantes, ao vivenciarem o carnaval, colocam-se frente a uma experiência cíclica do tempo, singularizando sua percepção da temporalidade vivida, marcando-a por uma ordenação cronológica que não se orienta fundamentalmente por datas fixadas pelo calendário cristão. Para além de uma experiência individual, os carnavalescos orientam-se, temporalmente, por referenciais coletivos outros, próprios da sua cultura.

\section{O Carnaval e o Ciclo Carnavalesco}

Embora atentos ao momento de maior dramatização do ritual - o desfile carnavalesco esta pesquisa traz a intenção de desvendar a cultura deste grupo através da análise das práticas e representações dos seus sujeitos-personagens no cotidiano da Escola de Samba referida.

Buscando reconhecer suas formas de interação e as múltiplas redes de sociabilidade que se cruzam através da Escola de Samba, mapeei os espaços sociais por onde se espalham estas redes que a integram. Através da observação do seu cotidiano, busquei sua forma de conceber e

\footnotetext{
${ }^{1}$ GUTERRES, Liliane S. “Sou Imperador até morrer”. Um estudo sobre identidade, tempo e sociabilidade em uma Escola de Samba de Porto Alegre. Porto Alegre: PPG Antropologia Social/UFRGS, 1995. (Dissertação de Mestrado).
} 
organizar a temporalidade vivida, desvelando os códigos simbólicos e referenciais utilizados que apontam para uma concepção singular do tempo.

Proponho uma análise interpretativa do carnaval enquanto um processo ritual. A preocupação com o estudo do cotidiano vivido pelos Imperadores $^{2}$, remete a uma esfera outra que não a do carnaval, ao antes e o depois do momento ritual propriamente dito, compreendendo-o enquanto pertencente a um processo. $\mathrm{O}$ ritual abarca o que o precede e o que vem depois. Marc Piault pergunta:,"como saber onde começa e onde termina um ritual?"3.

Desta forma, partindo da concepção de ciclo ritual carnavalesco - e não carnaval, na medida em que este restringe-se às cinco noites de folia e àquele ao período de aproximadamente um ano que cobre a distância entre dois carnavais ${ }^{4}$-, acompanhei dois ciclos rituais ${ }^{5}$ na certeza que um ritual não reproduz completamente o ritual que o precedeu e que o momento ritual não se esgota ou não é passível de análise apenas no seu momento de efervescência.

O carnaval é vivenciado, por aqueles que dele participam, como um tempo especial, um tempo de festa demarcado por uma cronologia cíclica anual ${ }^{6}$. No ciclo carnavalesco, o desfile realizado pelas Escolas de Samba, sinaliza ao mesmo tempo, o ponto de chegada e de partida do processo ritual.

Na fala dos Imperadores, a noção de processo, de ciclo ritual, é expressa no desejo de "fazer carnaval o ano todo". Uma baiana da Escola, num programa da TVE, afirmava: "eu faço carnaval o ano inteiro", enquanto assinalava a necessidade de se abrir espaço, nos meios de comunicação, para os carnavalescos nos períodos além do carnaval. Na Ata de criação da Ala Povo Meu consta sobre a “(...) filosofia da ala que pretende trabalhar o ano inteiro”. Para o presidente da Escola “existe carnaval o ano todo”, depois do desfile na avenida, mesmo nos

\footnotetext{
2 Esta entidade assina como Grupo Carnavalesco Imperadores do Samba e adotam a razão social "Sociedade Beneficiente Recreativa". Embora seja reconhecida e referida pelo grupo como "Escola de Samba", nunca constou e não consta oficialmente tal terminologia em seu nome, devido a retundância de termos: Escola de Samba Imperadores do Samba. Traz a ambiguidade de ser referida tanto como masculina ou feminina, conforme a situação: a Imperadores do Samba (então subentende-se Escola de Samba) ou o Imperadores do Samba (neste caso a concordância é com Grupo Carnavalesco, havendo ainda a variação - o Imperador). Imperadores é a denominação dada ao sujeito que participa, gosta e torce pela Imperadores do Samba.

3 Palestra proferida na V Reunião de Antropologia (Merco) Sul realizada em Tramandaí em 1995.

${ }^{4}$ Leopoldi define ciclo carnavalesco como "o período de tempo compreendido entre dois carnavais consecutivos" (1978:49).

5 Percorri assim, dois ciclos rituais completos: o carnaval do Gandhi (1994) e o carnaval do Monteiro Lobato (1995).

${ }^{6}$ O carnaval de Porto Alegre, atualmente, inicia na sexta-feira anterior ao domingo de carnaval O domingo de carnaval, ou domingo gordo acontece sete domingos antes do domingo que celebra a Páscoa da Ressure ição. Por sua vez o domingo de Páscoa é definido cronologicamente por ser o primeiro domingo seguinte à lua cheia posterior ao equinócio da primavera, fixada no dia 21 de março. Desta forma a Páscoa poderá ser celebrada entre os dias 22 de março e 25 de abril e, consequentemente, o carnaval poderá ser comemorado algumas vezes em fevereiro outras em março. Atualmente o carnaval não começa mais no domingo de carnaval mas na sexta-feira que o precede, totalizando então não mais três noites de festa mas cinco, devido o aproveitamento do fim-de-semana que o antecede.
} 
encontros informais, “fazendo um churrasquinho, tomando uma cerveja”, estão discutindo o carnaval que passou e planejando aquele que virá.

O fim de um carnaval define o início de um novo ciclo carnavalesco, é o recomeço de tudo. Guardados os aprendizados advindos da vitória ou derrota, a Escola de Samba reinicia todo o processo ritual, na incerteza de um novo sucesso ou fracasso. Nos ensaios em quadra o diretor de harmonia lembra os componentes: "fomos campeões do carnaval passado".

A noção de que o ano começa depois do carnaval é recorrente entre os que participam da festa. Goldwasser $(1975,165)$ já chamava a atenção que “o ano do 'sambista' se conta de carnaval a carnaval". Os carnavalescos movem-se numa temporalidade própria, onde o ano cronológico inicia na quarta-feira de cinzas após o carnaval, independentemente em que dia do ano estará fixada. Após o carnaval de 1994, um dos radialistas da Rádio Princesa declarava em seu programa: "Quando passa o carnaval é que começa o ano, tem revisão, tem eleição, um monte de coisa ... agora é que nos damos conta da realidade, a revisão constitucional, a URV...”.

A dissonância temporal existente entre o preparo do carnaval e o desfile propriamente dito faz com que os carnavalescos acabem por singularizar sua vivência temporal de tal forma que o ano carnavalesco estará sempre um ano à frente. Cavalcanti esclarece:

"Como os preparativos se iniciam num ano, e o carnaval se realiza no ano seguinte, desde que o processo se põe em marcha, estamos no carnaval do ano seguinte" (Cavalcanti, 1993,83).

$\mathrm{Na}$ fala dos Imperadores essa representação de um tempo diferente da noção de tempo ocidental - o tempo do calendário, linear e acumulativo - transparece. Durante um almoço-galeto na quadra de ensaios, em dezembro de 1993, uma baiana dizia: "minha netinha vai desfilar ano que vem". Referia-se ao carnaval de 1995, evidenciando que em dezembro de 1993, por já viver o carnaval de 1994, desloca-se temporalmente para viver o ano de 1994. Os meses de 1993 serão vividos e recordados como pertencentes a um ano seguinte, 1994, pois será neste ano que acontecerá o carnaval que preparam e esperam.

Esta sucessão de rituais leva o grupo a construir uma representação singular do tempo lembrado. Ao recordar os 37 carnavais passados, a mémoria não retêm o ano cronológico, mas o identifica ligando-o ao tema-enredo apresentado pela Escola de Samba. Alguns carnavais muito lembrados são os do "ano do México”, “ano do chinês”, “ano do Lupi”, entre outros. Uma 
diretora não lembrava o ano da fundação da sua ala mas sabia que "foi no ano do Falcão"7 . Dois carnavais, entretanto, são referidos quanto a sua data cronológica e situações vividas e não pelos temas-enredos apresentados. Foram momentos importantes da Escola, o "carnaval de 75”, também conhecido como "o ano do Povo Meu” (nome do samba de quadra), inaugurou uma nova forma de desfilar quando pela primeira vez organizaram alas. No "carnaval de 86”, “o ano da chuva”, a Escola passava por sérios problemas financeiros e administrativos que configurando um período de “crise”. Sobrepõem aqui diferentes mas complementares referências temporais.

O tempo do carnaval está ligado a outros enquadramentos temporais distintos e complementares. Pensar o carnaval enquanto processo ritual, exige reconhecer estes tempos complementares a ele, qual seja o tempo que o precede e o que o sucede.

Entre os Imperadores uma referência clara ao ciclo carnavalesco aparece na fala êmica quando revelam sua percepção de três tempos distintos constituindo o período de aproximadamente um ano que cobre cada ciclo ritual: o tempo do "carnaval”, o "pós-carnaval" e o “pré-carnaval”. Tempos especiais porque guardam certas características específicas que os definem e contrapõem o tempo ritual ao tempo que precede e antecede a festa.

Os integrantes do grupo os representam de diferentes maneiras. Estes tempos rituais não são definidos cronologicamente, nem o carnaval possui uma data fixa nem seus tempos complementares. Percebi que no grupo estudado, estes tempos eram demarcados pelo trabalho pelo processo de confecção do desfile, e pela sociabilidade compartilhada entre os membros do grupo.

O carnaval é representado como o tempo da performance ritual, dos desfiles das Escolas de Samba na avenida, quando as relações sociais, construídas através da Imperadores do Samba estarão intensificadas ao extremo. O pós-carnaval é atualizado na fala do grupo como um tempo de descanso e "esfriamento" das interações estabelecidas no período imediatamente anterior. O período de pré-carnaval, por sua vez, é representado como um tempo de preparar o carnaval e de crescente sociabilidade.

Esta construção temporal está conectada a situação e contexto em que ocorre e ao o envolvimento da pessoa com a Escola de Samba e o desfile. Para os diretores e o grupo de trabalho, o pré-carnaval inicia logo que é escolhido o tema-enredo, para o figurinista quando começa desenhar as fantasias, para o componente quando começam os ensaios e assim sucessivamente. Ao ativar cada um dos elementos rituais o grupo demarca o tempo que é vivido

\footnotetext{
${ }^{7}$ Respectivamente: 1968 - "Uma festa no México"; 1971 - “China 400 séculos”; 1993 - Lupicínio Rodrigues e 1988 - "Das glórias dos gramados um rei entre os imperadores".
} 
como pré-carnaval, que contrasta com o tempo de "não fazer o carnaval" (o pós-carnaval) e o tempo de desfilar (o carnaval).

Embora distintos, os tempos rituais podem se sobrepor cronologicamente, de tal forma que, um mesmo período de tempo pode ser compreendido como pertencendo ao pós-carnaval ou pré-carnaval, dependendo de quem o está definindo. A "Entrega de Prêmios" do Carnaval 1993 realizada em maio pela Associação (quando, a Imperadores já havia escolhido seu tema "Gandhi” e, portanto, entrava em período pré-carnavalesco) foi considerado por ela como um evento pós-carnavalesco.

\section{O pós-carnaval: tempo de descanso, quando "é só nós mesmo"}

Pós-carnaval é uma categoria que aparece na fala dos diretores da Imperadores do Samba e da Associação das Entidades Carnavalescas . Entre os participantes de forma geral, este período de tempo também recebe a denominação de “depois do carnaval”. Muitos outros não nominam este período mas reconhecem nele um tempo especial, distinto do carnaval e do tempo que o precede, um momento de "não fazer carnaval", pois o ritual já aconteceu e o próximo ainda não começou a ser feito.

Iniciando depois do carnaval - do desfile na avenida - o pós-carnaval estende-se até o recomeço do envolvimento do sujeito com a preparação de um novo desfile. Esta retomada do envolvimento com a Escola de Samba, se dá, via de regra, através do trabalho e da sociabilidade, e determinará o fim do pós-carnaval e a inauguração do pré-carnaval.

O Pós-carnaval é o momento em que a Escola pára de “fazer carnaval”, pois não trabalha diretamente na confecção do próximo desfile. Entretanto, enquanto a diretoria aguarda as inscrições de temas-enredo - pois depende dele para desencadear os outros elementos constitutivos do ritual -, o carnaval, se não pode ainda ser executado, pode ser pensado e discutido por seus diretores. $\mathrm{O}$ diretor de carnaval reclama para si a responsabilidade primeira de “imaginar" o carnaval:

$$
\begin{aligned}
& \text { “eu ... só eu imagino o carnaval antes. Depois do carnaval } \\
& \text { imaginado, pensado, eu passo para o presidente, (...) sem o tema } \\
& \text { eu já tô com o carnaval imaginado”. }
\end{aligned}
$$

\footnotetext{
${ }^{8}$ A Associação das Entidades Carnavalescas de Porto Alegre e Estado do Rio Grande do Sul (AECPARS) foi criada nos primeiros anos da década de 60 .
} 
O pós-carnaval, para um diretor que possui envolvimento máximo com a Escola de Samba, inicia após as comemorações da vitória ou o inconformismo da derrota e se estende até a reativação do processo ritual com a escolha do tema-enredo para o desfile do próximo ano. Para um simpatizante da festa, caso extremo onde o envolvimento com a Escola de Samba é eventual e passageiro, o pós-carnaval é um longo período, pois só voltará a se envolver com as Escolas de Samba nos meses finais do ano, quando frequentar os ensaios em quadra. O grau de envolvimento da pessoa com a Escola influenciará sua representação deste tempo que sucede ao carnaval como curto ou longo. Para Turco, diretor de carnaval, o pós-carnaval caracteriza-se como um tempo de curta duração:

“(...) é o período de descanso que a gente só pensa o carnaval, não age, é o mês de finalzinho de fevereiro, se o carnaval é fevereiro, até a metade de março, isto é o descanso ...tu descansa só o corpo mas a mente não descansa porque a gente fica pensando já pro próximo ano ...é um período muito curto, é esse mês aí certinho que a gente tem”.

Para os diretores o pós-carnaval de 1993 foi breve, visto que uma semana após sua vitória com "Lupi", já divulgaram o novo tema-enredo para o carnaval de 1994 e, consequentemente, o trabalho de preparação do carnaval foi iniciado. O pós-carnaval de 1994, por sua vez, foi mais longo, coincidiu com o tempo de eleição da nova diretoria para o próximo biênio o que adiou toda e qualquer definição carnavalesca para o período posterior a eleição. Nos anos pares, anos de eleição, o pós-carnaval da Imperadores do Samba volta a se estender.

O resultado da competição também interfere na configuração da duração e representação do pós-carnaval. Será um tempo de vitória ou derrota. A vitória raz a festa, a alegria e brincadeira para dentro de quadra, assim foi no carnaval 1993, 1995 e 1996 com Lupi, Monteiro Lobato e Perfume. Com a vitória ocorre uma sobrevida dos encontros do grupo, destinados a um tempo de descanso, pois são realizadas várias festas comemorativas ao campeonato conquistado na avenida.

Em 1993, festejaram três noites seguidas. Cantando incessantemente o samba-enredo campeão, embalados pela bateria e pelas inúmeras cervejas consumidas, os dirigentes davam entrevistas emocionadas, com indisfarçavel prepotência ("deu o que tinha que dá, o que todo mundo já sabia, que a Imperador é a melhor”), remetendo a vitória ao “inevitável”, mas ao mesmo tempo lembrando a participação coletiva ao agradecer as alas e os componentes. $\mathrm{Na}$ 
quadra, a cada encontro, abraços, felicitações e elogios mútuos enquanto recordavam passagens do desfile realizado. Com a vitória vem a confirmação pública daquilo que, segundo eles, já tinham certeza: apresentaram o "melhor" desfile de carnaval da cidade. O interesse de uma competição, analisou Caillois (1990:35), está "no desejo de ver reconhecida a sua excelência num determinado domínio".

Festas comemorativas da vitória podem ainda se realizar meses após o carnaval. Em 1996, passados dois meses do desfile, a Imperadores promoveu a "Festa do Bicampeonato" preenchendo seu período de pós-carnaval prolongado (novamente ano de eleições) com novas comemorações. Festas comemorativas ao carnaval passado. O pós-carnaval, é representado como um tempo ligado ao carnaval que passou, e não ao carnaval que virá.

A derrota, por sua vez, traz o inconformismo e a indignação para dentro do grupo além de provocar sua dispersão, quase instantânea, no período imediatamente posterior ao carnaval. É um tempo onde os conflitos se deixam mostrar com mais intensidade, afloram situações de animosidade entre o grupo e os avaliadores que os desclassificaram, entre os membros da Escola perdedora e da campeã ou mesmo envolvendo Imperadores entre si. É um tempo de avaliações, debates e comentários acerca do desfile que passou.

Em 1994, a não conquista do bi-campeonato com Gandhi, trouxe indignação e inconformismo para dentro da Imperadores do Samba. Um diretor da Escola ao me ver dizia: “escreve aí no teu caderninho, escreve aí, isso é roubo, é roubo". Discutiam incessantemente a perda de pontos nos quesitos música-enredo e tema-enredo e a palavra mais amena que utilizavam para definir o avaliador, autor da baixa pontuação, era "safado”. A derrota suscitou a auto-avaliação do grupo frente às falhas de desfile identificadas pelos avaliadores, mas não se conformaram, em nenhum momento, com a perda de pontos. O presidente insistia: “desta vez a gente sabe que o resultado na avenida é secundário”. O diretor de ala expressava sua surpresa: "não podemos fazer melhor do que fizemos, o Imperador desfilou como nunca na vida dele, Porto Alegre nunca viu um desfile como o nosso". A busca de vitórias é uma das diferentes formas de grupos se firmarem e, simbolicamente, destruírem o outro. Segundo Lévi-Strauss (1976), vencer no jogo é uma forma simbólica de “matar"o adversário. Para Simmel, nas competições, o conflito se estabelece de forma indireta:

“A motivação subjetiva e antagonista conduz assim à realização de valores objetivos e a vitória na luta não é realmente o sucesso da luta em si, mas, precisamente, da realização de valores exteriores a ela"(1983:137). 
Após a derrota, a Escola diminuiu significativamente o seu número de encontros na quadra de ensaios. Não foram promovidas festas e os costumeiros churrascos de sábado à tarde tiveram pouquíssimos frequentadores. A derrota provocou uma transparência maior desse tempo de descanso ou férias, visto que afastou da quadra de ensaios não só componentes, como também alguns diretores do grupo de trabalho, sempre presentes. Estes afastamentos os reintroduz em outras redes de relações não mediadas pela Escola de Samba.

No tempo que sucede o carnaval, são reduzidas drasticamente as interações entre o grupo, os componentes deixam de frequentar a quadra e retornam à rotina da sua vida diária de trabalho e afazeres pessoais. Os ensaios e reuniões estão suspensos provocando afastamentos das relações sociais antes tão intensificadas com o carnaval. Para a baiana que afirmava "a gente sente falta até do olho-grande...”, este é um tempo de separação e afastamento social.

Os encontros entre Imperadores na quadra de ensaios, tão intensos no período do carnaval, no período de pós-carnaval acabam por restringirem-se apenas às pessoas ligadas ao grupo de trabalho que dirigem-se no sábado à tarde para os tradicionais churrascos em quadra. Reunem-se em círculo, em uma "roda”, onde todos podem participar das conversas, geralmente, rindo de uma situação narrada ou de um acontecimento presente. Significativamente, os Imperadores estabelecem entre si, uma interação lúdica que se aproxima das "relações jocosas" conceito formulado por Radcliffe Brown:

“...uma peculiar combinação de amizade e antagonismo. O comportamento é tal que em qualquer outro contexto social ele expressaria e geraria hostilidade, mas tal atitude não é a sério e não deve ser levada a sério. Há uma pretensão de hostilidade e uma real amizade. Posto de outro modo, é uma relação de desrespeito consentido".(In OLIVEIRA, 1979:166)

O pós-carnaval é um tempo de comentar o desfile que passou, quem desfilou ou não, ou ainda quem "apareceu na $T V$ ”. Acontecimentos ocorridos em carnavais antigos são agora também recontados através de uma performance lúdica. Durante os churrascos de sábado à tarde, a história da Escola de Samba era revelada pelos que ali estavam, fundadores, diretores atuais e antigos componentes. As vitórias e derrotas, os acontecimentos pitorescos, as mágoas e alegrias embalavam as recordações reveladas pelo grupo, contadas de forma irreverente. Lembravam, por exemplo, entre gargalhadas, o ano que as alegorias foram feitas num barracão no bairro da 
Glória. Nesta época, os carros eram feitos como uma peça única, sem encaixes que possibilitassem seu desmonte, de tal forma que foi necessário destruir a parede da casa para a saída da alegoria. Mesmo que a situação narrada não seja engraçada em si, quando lembrada é feito de forma jocosa, através de brincadeiras.

O tom alto das conversas possibilitava que todos compartilhassem as recordações, acrescentando um detalhe a mais ao que estava sendo revelado. Quando esgotavam-se as brincadeiras referentes a alguma recordação, outros lançavam mais lembranças provocando novas risadas. Nestes momentos, os que participaram ou tinham conhecimento do acontecido lançavam suas experiências para o grupo, os outros, que não tinham histórias para contar, ouviam e riam muito nos momentos engraçados. O pós-carnaval, portanto, é um tempo de lembrar e reviver os carnavais que passaram, em nenhum outro momento as lembranças do grupo emergiram com tanta força e prioridade como neste momento.

Com a desarticulação das alas os componentes deixam de se formar enquanto grupo mas permanecem em contato através de outras redes de relações, tais como vizinhança, trabalho, parentesco, e amizade.

\section{Pré-carnaval: tempo de "fazer carnaval", quando o "povo tá chegando"}

A denominação pré-carnaval é utilizada pela Associação ${ }^{9}$ e pelos dirigentes das Escolas de Samba em geral, entre os participantes de forma geral, é mais usual definí lo como o "tempo dos ensaios”, pois para eles abrange, principalmente, a época em que a Escola de Samba passa a ensaiar semanalmente para preparar sua apresentação musical e coreográfica.

O pré-carnaval é identificado como o tempo destinado ao preparo do carnaval. É o tempo de "fazer carnaval", de recomeçar os preparativos rituais, quando novamente é acionado o processo que culminará no próximo desfile da avenida. Não é um tempo regulado ou determinado cronologicamente antes, será determinado pelo inicio do processo ritual que seguirá, salvo pequenas variações, o seguinte desenrolar: escolha do tema-enredo, escolha do samba-enredo, início dos ensaios (bateria, grupo de harmonia e destaques), definição e desenho dos carros alegóricos e das fantasias, confecção do organograma (representação gráfica da disposição das alas, destaques e carros alegóricos em desfile, “como a Escola vem”), cooptação de componentes e confecção dos carros alegóricos e fantasias.

\footnotetext{
${ }^{9}$ Segundo a Associação, os eventos que compunham o “calendário pré-carnavalesco” do carnaval de 1994 eram: Julho/1993 - Curso de Jurados e Festival de Sambas de Exaltação das Escolas; Setembro/1993 - Festival de SambasEnredo do Grupo 2, Grupo 1B e Grupo 1A; Outubro/1993 - Lançamento do disco dos Sambas-Enredo; Novembro/1993 - Concurso de Rainha do Carnaval de PoA; Fevereiro/1994- Muamba Oficial.
} 
Com a abertura das inscrições para tema-enredo o grupo volta a trabalhar ativamente. $\mathrm{Na}$ secretaria um cartaz fixado no mural anuncia a "agenda 94" dos meses de maio a setembro, são festas, reuniões, prazos para a entrega do tema-enredo, dia da sua escolha, prazos para inscrição de samba-enredo e as datas para as suas eliminatórias.

Para os dirigentes, a escolha do tema-enredo é que definirá o início da preparação do ritual, conformando um novo tempo, o pré-carnaval. No discurso do grupo aparece como o elemento que propiciará a "arrancada para o carnaval”, A posterior definição do sambaenredo é mais um momento onde é a temporalidade vivida é reafirmada e demarcada como précarnaval. A existência de um novo samba-enredo, concreto, cantado, é também demarcador de um tempo, relacionado com o fazer carnaval.

O tema-enredo e o samba são quesitos avaliados na competição-desfile e portanto sua definição é um momento muito importante no processo ritual. É o cumprimento dessas definições que permite que outros setores sejam acionados, é o caso das fantasias e alegorias que podem agora começar a ser concebidas. A escolha do novo tema-enredo não acontecem em mês certo, a Imperadores do Samba definiu-os em fevereiro de 1993, junho de 1994 e maio de 1995. Esta variabilidade recebeu, respectivamente, denominações de "cedo" e "tarde ". Anos pares, quando há eleição presidencial na Escola, os temas definem-se mais "tarde”. Com o novo samba-enredo, os ensaios poderão recomeçar. Os primeiros ensaios noturnos redefinem o tempo pré-carnavalesco como o "tempo de ensaios" para a bateria, destaques e alas.

O pré-carnaval é um tempo fortemente caracterizado por demarcar inúmeras comemorações, são "festas de arrancada”, "início oficial dos ensaios", "primeiro ensaio geral”. Os ensaios diários só começam a partir de janeiro pois "as pessoas tem outros compromissos, trabalho”. A partir desta data, haverá ensaios de terças a domingos, e será controlada a dedicação exclusiva dos destaques e diretores aos ensaios.

O carnaval passa a ser esperado em contagem regressiva, a cada ensaio o divulgador relembra quantos dias faltam para o carnaval. Todas as alas serão organizadas a partir dos ensaios de sexta e sábado mas o número final de componentes que desfilarão só se definirá nos últimos ensaios.

No pré-carnaval os momentos de rivalidade, entre as Escolas de Samba que competem diretamente em um mesmo grupo, tornam-se frequentes e tensionam as relações entre os Imperadores e os "outros". Ter uma representante na Corte (rainha ou princesas) ou o "melhor samba", por exemplo, são motivos para estratégias competitivas, pois levam a situações de prestígio e sinalizam primeiras vitórias sobre as Escolas de Samba oponentes. 
“Entrar pro barracão” significa inicializar o último elemento ritual, demarca o ápice do pré-carnaval, pois quando entram para o barracão o carnaval está "muito próximo". A cada carnaval, a Escola tem investido mais dinheiro na esfera visual. A primeira e a segunda semana de trabalho no barracão terá um ritmo de trabalho lento se comparadas às posteriores, quando aumentará o número de trabalhadores e tarefas a serem cumpridas. Inicia com a ferragem, seguem os trabalhos de carpintaria, eletricidade, e "o pessoal da arte" - alguns trabalham profissionalmente em outros meios culturais como teatro ou são alunos universitários e, outros são cooptados entre os componentes da Escola. Como são muitos os carros alegóricos a serem construídos num espaço limitado, as etapas da sua confecção, ferragem, marcenaria e arte, podem se sobrepor temporalmente de forma que se realizem simultaneamente.

O término do período de pré-carnaval pode se sobrepor ao tempo do carnaval. Quando inicia oficialmente o carnaval da cidade, na sexta-feira anterior à quarta-feira de cinzas, para os diretores da Imperadores do Samba, ainda é pré-carnaval, pois ele "só termina quando entramos para a avenida”.

Outra forma de representar o tempo de pré-carnaval é, não pelo trabalho realizado, mas pela sociabilidade compartilhada pelo grupo, é um tempo que abriga a reaproximação do grupo com a Escola de Samba e com o carnaval de forma geral. O que se vê durante o pré-carnaval é um calendário repleto de festividades, são inúmeros eventos sociais que congregam aqueles que de alguma forma participam do carnaval da cidade, sejam eles componentes das Escolas de Samba ou meramente simpatizantes da folia. São encontros festivos, onde sempre há músicas, bebidas e comidas. São festas, bailes, shows, ensaios, churrascos, reuniões, chás, aniversários, almoços, jantas, coquetéis, pagodes e rodas de samba, realizados nas quadras de ensaio, em clubes, bares, ruas e casas da cidade. Conforme avança o pré-carnaval (e aproxima-se o carnaval) o número de eventos é intensificado e, geralmente, acabam por concentrar-se nas quadras de ensaios - que são, por assim dizer, o locus privilegiado de interações entre aqueles que participam do carnaval de alguma Escola de Samba.

Os churrascos de sábado à tarde continuam e, com o período de inscrição de temasenredo, a quadra passa, novamente, a ser frequentada por pessoas que não pertencem diretamente ao grupo de trabalho. Embora, o simples componente ou simpatizante ainda não tenha retornado à quadra, já se percebe um fluxo maior de pessoas que discutem e palpitam sua preferência por este ou aquele tema inscrito.

O grupo recomeça a se encontrar em “reuniões” nas terças-feiras à noite. Não são reuniões formais, pois será nas saídas da sala, no vai-vem dos diretores, privadamente, que assuntos importantes serão discutidos rapidamente. As reuniões formais, geralmente ocorrem na 
casa dos diretores, privadamente, longe do burburinho da quadra. Se reuniões acontecem na secretaria, então a porta é fechada tornando-se uma barreira intransponível mesmo para muitos Imperadores da casa. Não há argumento que convença o grupo a se abrir, "o que acontece aqui só a gente sabe”, diz o presidente. Os conflitos internos que surgirem não devem cair no conhecimento do público mais amplo, caso aconteçam, surge logo uma "versão oficial” do acontecido de forma que não haja desagregação entre os diretores e o grupo de trabalho, que sempre procuram preservar sua imagem de união.

Nas "reuniões" das terças-feiras encontram-se diretores, o grupo de trabalho, Imperadores, produtores de festas, sócios, que conversam animadamente sobre questões nacionais, locais, assuntos específicos e "novidades” do carnaval, entre risos, recordações e intensa movimentação corporal. São momentos de descontração, conversando em tom alto de voz, a agitação é tamanha que muitas vezes não se consegue decifrar o assunto discutido pois as vozes se sobrepõem compondo um burburinho generalizado.

Os encontros do grupo neste início de pré-carnaval, não se restringe às quadras, à sociabilidade e aos momentos de lazer, continuam acontecendo nos clubes e bares da cidade. Algumas vezes Imperadores saem juntos de quadra para frequentar alguma festa ou bar no sábado à noite. Se são convites oficiais de outras Escolas de Samba, programam com antecedência vestirem roupas vermelhas e brancas e o local de encontro em frente à festa para entrarem juntos. Assim como pessoas de outras Escolas participam das festas da Imperadores do Samba, também os Imperadores acompanham eventos em outras Escolas rivais, são momentos de sociabilidades importantes pois então passam a se identificar com o carnaval de forma abrangente e não apenas com a sua Escola de Samba.

São festas de aniversário de Escolas de Samba ou de carnavalescos, coquetéis da Associação ou festas que contarão com a presença do grupo-show da Imperadores do Samba e terão a presença de vários representantes das Escolas de Samba da cidade. Ocorrem também diversas festas particulares, principalmente festas de aniversário de componentes ou diretores, e os convidados, familiares, amigos e colegas de trabalho, geralmente tem em comum o gosto pelo carnaval mas não necessariamente a mesma Escola de Samba “de coração”. Em 1993 a baiana Marta, da Imperadores do Samba, comemorou seu aniversário na quadra de ensaios da Candinha (já desfilou com esta Escola, vizinha a sua residência) chamando os "convidados" pela Rádio Princesa AM. Estavam presentes amigos seus de várias Escolas de Samba, entre eles, o presidente do Bambas da Orgia, a escola de maior rivalidade com a Imperadores do Samba. Durante a festa, as conversas giram em torno do preparo do carnaval, comentam boatos sobre outras Escolas de Samba ou sobre acontecimentos que envolviam pessoas ligadas ao carnaval. A 
esposa de um Imperador comentava com expressão inconformada: “é 24 horas de carnaval por dia”.

No período de pré-carnaval ocorrem vários almoços e jantas promovidos pela Imperadores do Samba através do seu Conselho Deliberativo, diretoria executiva ou mesmo por alguma de suas alas. São galetos ou churrascos que trazem uma atração especial, como a Escolha da Rainha Mirim, apresentação de um novo destaque ou a apresentação do grupo-show. Van Gennep nos lembra que a comida é um agregador social:

\footnotetext{
"a comensalidade, ou rito de comer e beber em conjunto (...) é claramente um rito de agregação (...) criam continuidade do vínculo social entre as pessoas, com a mesma significação que a 'comunhão"” (1978:43).
}

Se almoço, estende-se até o início da noite, se jantar, após há baile. Na fala dos diretores de ala, os motivos propiciadores destes eventos podem ser econômicos e de integração: “a nossa festa não visa lucro, é reunir o pessoal para comprar o tecido" ao mesmo tempo que "servem prá integrar o pessoal”. A descrição que Zaluar (1985:123) faz das refeições comunais entre o grupo estudado, de igual forma traduzem os almoços e jantares observados entre Imperadores: "sublinha-se a alegria - de fazer junto, de comer junto, de estar junto (...)".

A posse da nova diretoria para o biênio 1994/1996, o coquetel comemorativo aos 35 anos da Imperadores do Samba e a inauguração da churrasqueira foram comemorados sem a venda de ingressos e isso os torna casos especiais pois, via de regra, eventos onde há consumo de comidas, são pagos. O público que participa, então, é seleto, na medida em que será composto por Imperadores, sua maioria, e também pelos convidados conhecidos, bambistas e Imperianos, por exemplo. Estes eventos especiais são momentos que requerem discursos do presidente ou do diretor de harmonia. Seguem, invariavelmente a mesma linha, recolocando sempre as mesmas questões: a importância de "manter o grupo unido", a força da "comunidade Imperador" e demarcação do "novo" tempo, referido como "arrancada para o carnaval".

Durante o pré-carnaval as apresentações do grupo-show na cidade se multiplicam, participam de promoções da prefeitura no Largo Glênio Peres, no Baile Municipal da Sogipa ou mesmo em promoções anuais como a "Descida da Borges", quando fazem uma muamba particular no centro da cidade. Não são raros shows em outras cidades da região, quando então deslocam-se de ônibus, retornando para a quadra apenas na manhã seguinte. 
As festas e ensaios são os encontros que mais público congregam, são milhares de pessoas $^{10}$. Chamo de festas os eventos noturnos que trazem como principal atração a apresentação de um grupo musical ou um cantor de projeção local ou nacional. Também podem ser nominadas enquanto baile ou simplesmente show. Os ensaios, por sua vez, são festas porém direcionadas para a preparação do desfile de carnaval, a atração maior é o próprio ensaio dos destaques, grupo de harmonia e bateria que treinam passos e ritmos para o desfile na avenida. Há uma tendência do grupo a preencher com festas os tempos em que não há ensaio e, na época dos ensaios diminuir o número de festas, mas não há uma contraposição básica entre tempo de festa e “tempo de ensaio", mas sim entre o tempo de "não fazer carnaval” e "tempo de ensaio". Os ensaios também são festas, e é preciso estar atento para perceber como se interpenetram e se opõem em diferentes situações. Conforme o fim-do-ano se aproxima os componentes retornam aos ensaios, é então pré-carnaval para eles. O público cresce a cada encontro e em janeiro e fevereiro a quadra estava lotada nos ensaios de quarta, sexta e sábado.

As "grandes festas" em quadra selecionam um público de poder aquisitivo mais alto do que aquele que frequenta os ensaios. Entretanto, será nos ensaios que a presença de crianças se dará com mais nitidez, mas ali estarão também pessoas que pertencem a todas as gerações. Muitas vezes a família vai junta para um ensaio, Regina, tesoureira, já é bisavó e toda a sua família participa dos ensaios e promoções da Escola: sua filha Alda é secretária da bateria, sua sobrinha Mery, primeira secretária da diretoria executiva, sua neta Bianca, é atualmente segunda porta-bandeira, e sua bisneta, o bebê da casa, vez por outra está presente em quadra dormindo nos braços da mãe e dos amigos. A mãe de Regina, D. Eva, poucas vezes participa junto com os filhos, netos e tataranetos de algum evento em quadra pois sua saúde debilitada não permite excessos, mas "sempre que pode lá está”.

Nos primeiros ensaios a organização é ainda incipiente, mas, conforme aproxima-se o final do ano, o fluxo crescente do público exige uma organização rígida dos ensaios e os componentes da diretoria, coordenação e alas poderão ser reconhecidos por suas camisetas, que nas costas trarão grafadas seu papel social. Para um componente, o público das quartas-feiras seria diferente dos do fim-de-semana: "tu podes ver pelas roupas”. Composto por famílias, jovens estudantes que gazeam as últimas duas aulas e chegam em quadra com livros e pastas, trabalhadores que saem direto do seu trabalho ou pessoas que parecem ter ficado horas em frente a um espelho, as quartas-nobre transcorrem tranquilamente sem desavenças entre o público, mais comuns nos ensaios de fim-de-semana. Os ensaios de sexta-feira trazem um maior público

\footnotetext{
${ }^{10}$ É difícil precisar numericamente o público que lotas as festas e ensaios na quadra. Segundo um diretor, a quadra comporta de 3.500 a 4.000 pessoas, mas há quem contabilize 5.000 pessoas.
} 
que os de sábado, quem participou de um ensaio não participará de outro pois seria muito oneroso, exceção é claro, ao grupo de trabalho, diretores e destaques. Como nos ensaios “mulher não paga até as 11", elas são as primeiras a chegar, geralmente em grupos.

Nos ensaios há a preocupação de ensinar o público a cantar o samba-enredo, quando percebem que ele, de forma geral, participa para se divertir e não para ensaiar, o segundo puxador exaspera-se: "vocês estão pensando que estão num baile?".

A noção de festa enquanto "transgressão das normas sociais" (Vianna,1988:51), merece um olhar mais atento. A festa ao mesmo tempo que transgride, re-inventa códigos sociais que sinalizam a interação entre os sujeitos. Se transgride muitas das crenças e regras do cotidiano, por outro lado, reforça as regras criadas para os momentos de festa.

Tal qual o exemplo carioca, analisado por Cavalcanti, observou-se a diluição, no cotidiano carnavalesco, da oposição trabalho/festa.
"uma das alegrias do carnaval e uma de suas muitas subversões é certamente a dissolução da oposição trabalho e lazer, ou trabalho e festa. Não que a distinção em si seja irrelevante, mas aqui, nesse mundo que vivia para a festa, todo o trabalho era pontuado por festas, ritualizando e ressaltando aspectos essenciais do processo em curso"(1993:189).

Para os diretores, as festas são importantes não só por angariar fundos para o carnaval e "promover o nome da escola", mas também por propiciar o contato dos componentes com a agremiação carnavalesca em todos os períodos do ano, colaborando para que haja maior "sintonia" entre eles e o grupo de trabalho. São momentos extraordinários que comemoram algum acontecimento especial, portanto, toda a festa terá uma chamada, um motivo, que convença as pessoas a compartilharem desse tempo festivo. A festa motiva "arrumações" na quadra, que pode ser pintada ou ter novas instalações inauguradas especialmente, nos dias de festa.

Toda a diretoria da Escola estará envolvida como bilheteiros, portaria, "mestre de cerimônias" ou coordenação. A Escola contrata uma equipe de segurança para previnir e controlar eventuais brigas e desentendimentos entre o público ${ }^{11}$. Grandes festas é sinônimo de grandes filas, na bilheteria, entrada da quadra, na copa e banheiros. Nunca iniciam antes da meia-

\footnotetext{
${ }^{11}$ É proibido entrar com arma de fogo ou arma branca. Também são retirados pentes de cabelo considerados perigosos, tubos de desodorante com loló e faixas enroladas nos pulsos próprias para cheirar o produto.
} 
noite e não terá seu público definitivo antes da uma e meia da manhã. O consumo de bebidas, principalmente cerveja, é constante, nos intervalos dos ensaios centenas de pessoas acotovelamse em frente a copa, todos querem ser atendidos ao mesmo tempo e os atendentes não dão conta da demanda. A música serve como pano de fundo, contribuindo indiretamente para a diversão do grupo, o principal será a sociabilidade compartilhada, a presença de conhecidos, “as amizades”, são os namoricos e reencontros que torna a festa " $b o a$ ".

Os comentários da festa que passou sempre avaliam se ela foi boa ou não. O "bicho pega”, quando o público, que lota as dependências da festa, canta e dança animadamente. Para uma festa ser considerada "boa”, necessariamente ela deve estar “cheia”. O número de participantes de uma festa é dado importante de ser destacado quando ocorre a sua rememorização, muitas vezes ao perguntar sobre determinada festa que não compareci, ouvi a mesma resposta: "tava boa, tava cheia”. A insistência do grupo com esta questão é percebida em várias situações: se uma festa está lotada, o divulgador da Escola chama a atenção para a “lotação possessa”. Dirigindo-me para a festa de aniversário da baiana Marta, na quadra da Candinha, ouvia Tio Bagé $e^{12}$, o promotor da festa, na Rádio Princesa: “... a quadra está lotada, pedimos desculpas ao pessoal que já não encontra lugar para sentar...”; ao chegar em quadra, entretanto, notei que apesar de várias pessoas no local havia ainda metade dos lugares vazios. Muitas vezes foram-me solicitadas, durante as festas, fotografias de diretores ou componentes “com a "massa atrás".

A relação é, então, direta: festa boa, festa cheia, assim como "pouca gente”, "festa ruim". Da mesma forma, quanto mais cheio estiver o ensaio "melhor" ele será. A Imperadores do Samba, nos últimos anos vem sendo unanimamente aclamada como a Escola que tem os "melhores ensaios" da cidade, a confirmação vem dos próprios bambistas, Imperianos e componentes de outras Escolas que frequentam os ensaios da Imperadores. Nos ensaios para o carnaval de 94 os comentários, sobre a "quadra vazia” da Restinga, circulavam entre Imperadores e, para um Imperador, “o ensaio do Bambas é morto, sempre foi, sempre vai ser”.

Uma festa "boa" certamente terminará nas primeiras horas da manhã, por volta das seis ou sete horas. Como propaganda para a festa, o divulgador lembra os ouvintes da rádio que na Imperadores do Samba a festa "só termina quando o galo fica rouco". Como as festas terminam tarde (ou cedo da manhã), a Escola nunca promove, eventos matutinos, mesmo os almoços promovidos em quadra, acontecerão nas primeiras horas da tarde.

\footnotetext{
${ }^{12}$ Bagé é um conhecido produtor de festas, agencia shows com cantores e bandas portoalegrenses nos clubes e quadras da cidade e do interior do Estado.
} 
As "barcas furadas" são festas com pouco público e, para os rapazes da bateria, as que "não tem mulher". A falta de público é uma ameaça ao evento e antes que aconteça "tem que fazer um axé p'ro povo chegar”, dizia uma baiana. Em quadra, a chuva também sempre será uma ameaça para a festa, mesmo sendo parcialmente coberta, sua proximidade com o Rio Guaíba a torna vulnerável aos ventos fortes e gelados e então, para muitos, "a última festa do Imperador não foi boa porque estava frio e chovendo”. Se por um lado a chuva e o frio são considerados empecilhos aos eventos festivos do grupo, por outro, há uma explícita preferência ao calor e ao verão de uma forma geral. Nos meados do ano, época de outono, inverno, ou mesmo o início da ventosa primavera, as queixas em quadra são generalizadas, muitos deixam de ir porque dizem sentir frio e os que lá aparecem, muito agasalhados, passam o tempo todo reclamando da umidade do local.

As "visitas" de carnavalescos de outras Escolas de Samba ou figuras importantes do carnaval da cidade exigem um tratamento especial, são logo recepcionados e encaminhados para uma mesa. As baianas fritam pastéis rapidamente para levar aos diretores da outra Escola ou avaliadores do desfile. Se são destaques visitantes, participarão da roda de ensaios levados para dançar por uma baiana ou pelos próprios destaques da Imperadores. Da mesma forma ocorre quando Imperadores ou carnavalescos visitam outras festas, são recebidos formalmente, levados para uma boa mesa e servidos com tratamento preferencial, assim foi com Mestre Neri quando participou da festa de aniversário de 53 anos do Bambas da Orgia, não pagou ingresso e foi saudado pelo microfone.

Nos ensaios e festas, os espaços ocupados pelo público e Imperadores estão bem demarcados: quem trabalha para a realização do evento circula por todos os espaços da quadra, os componentes e diretores de alas permanecem próximos aos box das alas e no corredor que ali se forma. As famílias e seu grupo de amigos, assim como os convidados especiais, ocupam as mesas na área da churrasqueira ou onde elas forem colocadas. A área coberta imediatamente em frente ao palco é reservada para a bateria e a apresentação dos destaques. As salas da quadra são ocupadas por diretores ou fechadas à chave, secretaria, copas, departamento de carnaval, sala da coordenação são espaços de trabalho. O "grande público", indistinto, concentra-se, principalmente na área não coberta da quadra próximos à copa.

A noção de que as festas apontam para uma "superação das distâncias interindividuais"(Vianna,1988:51), portanto, deve ser relativizada quando observa-se os ensaios. Alguns diretores de alas, frente a um desentendimento em quadra, indicam a área descoberta como o local da briga, embora não pudessem afirmar tal fato pois estavam longe do local. Traçam, assim, uma fronteira invisível entre os espaços que cercam os boxes das alas e a 
churrasqueira, de outro, aquele da área descoberta. De um lado um espaço de Imperadores, nesse sentido privado, familiar e confiável, de outro, um espaço ocupado por aqueles que participam, genericamente, da festa, um espaço público e, potencialmente, perigoso.

As festas não só reavivam os laços sociais como também definem quais os laços são desejados ou não. A festa é um momento que propicia a interação entre os sujeitos que trazem identificações entre si mas diferentes histórias de vida. São momentos de sociabilidade inclusivos, por seu caráter coletivo, propicia contatos entre pessoas que no cotidiano não se conheceriam e, quando já se conhecem, estão envolvidos por uma estrutura que os coloca em posições sociais definidas, onde possuem outros papéis sociais a cumprir. A festa prioriza a integração e não a separação, embora esta esteja presente muitas vezes na festa. Viana está atento a esta questão, "a obviedade do holismo nos bailes":

(...) desconfiados, começamos a procurar os bastidores, qualquer indivíduo desgarrado no seio da massa, qualquer motivo para duvidarmos do totalitarismo do coletivo. Também encontramos traços do princípio de individuação com alguma failidade. Respiramos aliviados. E a 'dialética' holismo/individualismo continua a funcionar".(ib.:100)

Apesar de muitos participantes já chegarem à esta com grupos formados de fora, estes grupos podem se dissolver ou serem acrescentados de outros "amigos" encontrados na festa. Desta forma, as festas, não só reafirmam as relações entre sujeitos mas também podem propiciar a formação de novas relações e novas amizades.

Os participantes procuram estar sempre "bem vestidos". Zaluar (1985:103) já demonstrou que "o sair torna possível o encontro entre pessoas de diferentes níveis de renda e classes sociais, e esse encontro possibilita a comparação, a avaliação, a identificação através da roupa”. O “vestir bem”, nesse sentido, é percebido pelo grupo, como um importante aspecto na sociabilidade, pois "revelam a imagem que a pessoa faz de si e a imagem que desejam que os outros façam delas"(Macedo, 1986:197). Através da roupa pode-se manipular as representações da sua condição social, distanciando-os da identificação de pobre ao mesmo tempo que aproximandoos, através da imitação, ao vestuário em moda consumido pelas classes altas. Um ritmista da Escola dizia quando discutiam o assunto: "dentro do possível procuro me vestir bem por respeito a Escola”. Em um almoço informal em quadra, uma componente chegou, equilibramdose em cima de saltos altos e trazia, dentro de uma sacola, um sapato baixo de pano. Só o calçou 
quando sentou e seus pés tornaram-se ïnvisíveis" para os outros. Explicou: "faço questão de entar e sair dos Imperadores de saltos altos". De forma geral, sempre acompanham a moda atual, por ali passaram calças "boca de sino", blusas transparentes, tênis que ao pisar acendem luzes, mini-saias de lã xadrez. Mesmo comprando no setor informal, que trabalha com empresas especializadas em reprodução de vestuário classe alta e possuem preços acessíveis, percebe-se que investem muito dinheiro no vestuário. Vestem-se com esmero: camisas bem passadas, sapatos limpos, lenços, tudo isto envolvido por muito perfume.

A rede de fofocas e boatos que cercam os integrantes da Escola ou as "pessoas conhecidas" do carnaval recebem, nas festas e ensaios, possibilidade de expansão. Cruzam as redes de amizade, vizinhança e parentesco, ali muitos se reencontram e passam a atualizar as informações através de conversas informais. Comentam a vida alheia. No centro da cidade, em pontos tradicionais de encontro de carnavalescos, uma rede de comunicação estabelecida pela oralidade proporciona uma troca de informações forte e eficaz. Bittencourt Jr (1995) ao investigar os territórios negros do centro da cidade, nos informa da presença de carnavalescos na confeitaria Matheus e em outros locais tradicionais de Porto Alegre. Numa passagem em que cita um fragmento do seu diário de campo, revela a presença do Mestre Neri Caveira durante estes encontros, além de outras figuras conhecidas do carnaval.

Para uma diretora de ala que expunha o modelo da fantasia durante um ensaio na primeira semana de novembro de 1993, o público “por enquanto ainda tá chegando”. É o pré-carnaval que começa para componentes, simpatizantes ou curiosos, que passam a frequentar, com mais assiduidade, os ensaios da Escola para conhecer as fantasias, seu preço e condições de pagamento, ou simplesmente para se divertir. "Eles estão voltando”, grita jocosamente o presidente quando chega em quadra um componente da Escola. Conforme vai se aproximando o carnaval o ensaio vai crescendo em número de componentes que "vão chegando". O ingresso de novos diretores ou destaques que não possuíam afinidade com a Escola é anunciado, chamando a atenção que determinado componente “vem se integrar” à Escola. Se é um Imperador que estava “afastado", seu “coração vermelho” será lembrado.

O barracão, assim como a quadra, se constitui em um espaço de intensa sociabilidade não só entre os componentes do grupo, como entre os das Escolas de Samba pois, há vários carnavais, dividem o espaço de um mesmo armazém no porto. A relação com os vizinhos rivais é cordial, ouve-se comentários brincalhões a respeito de algo que aconteceu durante a semana do outro lado do tapume e, eventualmente, podem até emprestar ferramentas. O grupo evita comparações diretas entre os trabalhos, procuram sempre salientar o seu trabalho, as suas “inovações”, como um carro projetado como escada ou os leões de fibra de vidro no abre-alas. 
Neste espaço redividido, se espalham ferros, arames, pregos, tintas e espumas e o barulho de serras e soldadores domina todos os ambientes. A exaustão dos corpos exige um descanso sobre um carro alegórico semi-acabado ou marca a face dos que ali trabalham. Também marcam faces de contentamento com o trabalho realizado quando exibem orgulhosos sua arte. $\mathrm{O}$ cansaço é então valorizado positivamente, quanto mais trabalham.mais rápido as carcaças de ferro transformam-se em cenários monumentais, coloridos e criativos. Na medida que os carros alegóricos vão sendo feitos os espaços passam a se tornar reduzidos dentro do barracão, os trabalhadores que antes dormiam em cima das espumas que seriam utilizadas agora dormem diretamente sobre os carros alegóricos recém-construídos. Visitas de Imperadores estão liberadas, assim como a imprensa, mas muitos componentes não vão ao porto conhecer os carros alegóricos, sabem deles através de uma rede de informações traçadas a partir de alguém que viu e “disse que...”.

A relação entre diretores da Escola, conforme se aproxima o carnaval, torna-se mais tensa, surgem conflitos que podem gerar hostilidades entre os membros do grupo. Nesse sentido, a análise de Simmel (1983) a respeito do conflito são reveladoras, segundo este autor,

"As hostilidades não só preservam os limites, no interior do grupo,
como são muitas vezes conscientemente cultivadas, para garantir
condições de sobrevivência"(1983:126).

A oposição entre os membros do grupo não pode ser relacionada, meramente, a um fator social negativo, desarticulador mas, ao contrário, o conflito constitui-se em uma "força integradora do grupo", um "modo de conseguir algum tipo de unidade, ainda que através da aniquilação de uma das partes conflitantes"(ib.:122). O grupo estabelece códigos e regras que permitem os conflitos sem que o próprio grupo seja destruído, Simmel considera que "há uma relação entre a estrutura de cada grupo social e a medida de hostilidade que pode permitir entre seus membros". Nesse sentido, os afastamentos da Escola sinalizam estas fronteiras de proteção do grupo contra conflitos internos.

Nas muambas ocorrem mais uma possibilidade dos Imperadores se integrarem entre si e com os componentes de outras Escolas. No ônibus que os leva às muambas, o clima é de alegria e expectativa, alguns ritmistas vão cantando sambas enquanto outros põe a cabeça para fora das janelas para zombar com as meninas na rua. Gritam "sou Imperador até morrer". Quem participa das muambas, seja desfilando ou assistindo, veste as camisetas da Escola, tanto a do 
ano quanto antigas, ou roupas vermelhas e brancas, e não fantasias ${ }^{13}$. Identifica-se o público com certa facilidade. Grupos onde o vermelho é dominante (Imperadores), ou o azul (Bambas), verde (Restinga), amarelo (Império), indicam zonas de identificação com uma Escola de Samba particular.

O pré-carnaval, portanto, é um tempo de intensificação de festas, não só os encontros passam a se dar diariamente como, num mesmo dia, vários eventos podem acontecer simultaneamente, de tal forma que a bateria-show tem que se dividir para atender duas apresentações diferentes. Em alguns fins-de-semana o envolvimento dos diretores e do grupo de trabalho é extremamente intensificado, exemplo disso foi num fim-de-semana de dezembro de 1993: sexta-feira por volta das dez e meia da noite vários diretores já encontravam-se organizando uma grande festa com a Banda Brasil na quadra de ensaios, festa essa que terminou às sete horas da manhã. No sábado por volta de três horas da tarde estavam todos novamente reunidos em quadra e à noite encontraram-se às dez horas para apresentarem-se com o gruposhow no Baile da bateria da Candinha onde lá permaneceram até às seis e meia de domingo. Neste mesmo dia houve almoço promovido em quadra pelo Conselho Deliberativo quando logo após foi feita a Escolha da Rainha Mirim da Imperadores do Samba e, no fim de tarde, apresentação da bateria-show numa festa de rua organizada por uma Associação de bairro, retornando para a quadra por volta de nove horas da noite. Foram quarenta e oito horas de sociabilidade quase ininterrupta, quando diretores e grupo de trabalho estiveram presentes. Seguiram-se, até o carnaval, várias semanas com esta mesma intensidade.

\section{Carnaval: "o grande dia"}

O carnaval hoje, oficialmente, ocupa as cinco noites anteriores à quarta-feira de cinzas, sendo que a cada noite um grupo de Escolas de Samba fará seus desfiles. Entretanto, entre o grupo mais amplo, percebe-se formas diferentes de representar o tempo de carnaval.

A Rádio Princesa, já no início de fevereiro, anunciava "o carnaval chegou, o carnaval taî”, sua expectativa crescente em relação aos desfiles levava-os a identificar entes momentos que precedem a festa como já sendo carnaval. Por outro lado, para muitos Imperadores, o carnaval terá apenas um dia: na terça-feira à noite, quando desfilarem com a Imperadores do Samba na avenida.

\footnotetext{
${ }^{13}$ Exceção para os destaques, Comissão de Frente e baianas do grupo-show que desfilam fantasiados.
} 
A noite de "abertura do carnaval" da cidade, sexta-feira, coincide com o "último ensaio" da Escola, pois nos dias de carnaval não haverão ensaios ${ }^{14}$. Milhares de pessoas, Imperadores e "curiosos" participavam enquanto, no microfone, o divulgador anunciava recados das alas, fornecendo data e local das entregas das fantasias ou avisando que ainda havia vaga para um componente (provavelmente por desistência) em determinada ala. O horário de encontro da bateria na quadra de ensaios, para de lá seguirem juntos para a avenida, era incessantemente repetido, assim como o horário de concentração para os componentes da Escola.

Já há alguns anos o "último ensaio" acontece na sexta-feira, segundo os diretores, o intuito da Escola é "preservar" os destaques e "artistas", dando-lhes oportunidade para "concentrar" e descansar antes do desfile. Muitos destes artistas, como o puxador Medina, procuram se resguardar dos espaços de festa durante o carnaval. Seu cotidiano de ensaios noturnos e sociabilidade extremada, agora, no tempo ritual, é invertido e englobado, por um tempo de permanência doméstica e concentração total para o desfile:

“fico em casa, eu não posso dá oportunidade, dar chance ao azar, depois eu tô passeando pela avenida, arrumo uma briga por perto, alguém passa e dá uma pedrada, sabe? uma arma, qualquer coisa, e vem o Imperador na cabeceira e o Medina tá no pronto-socorro ou coisa assim ...não. Fico em casa, esperando minha hora, depois então eu faço a minha festa”.

Com o término dos ensaios, os diretores e o grupo de trabalho centralizam suas atenções para o trabalho de barracão e o acompanhamento dos destaques e alas. Surgem problemas urgentes como o não pagamento da fantasia da Porta-Bandeira que exigem uma resolução imediata. Os diretores circulam nervosos e agitados entre a quadra de ensaios e o barracão, acertando os últimos detalhes do desfile. O clima é de tensão e expectativa.

Nas casas dos diretores de alas a movimentação também é constante, ali funcionam as oficinas de costura, bordado e chapelaria da maioria das alas. A sede da Ala Inovação está na residência da sua presidente, Vera. No sábado de carnaval ainda terminavam fantasias e chapéus para os componentes de última hora: “peguei um componente ontem”, dizia ela, orgulhosa por ter condições de assumir este trabalho. Na cozinha, um cruzamento de varais sustentavam chapéus dependurados, numa sala intermediária, a parte da costura e as fantasias prontas, na sala

\footnotetext{
${ }^{14}$ De forma similar, salvo exceções, as outras Escolas de Samba da cidade também encerram seus ensaios neste dia.
} 
da frente, tomando completamente o ambiente, adereços e mais chapéus. A maioria dos componentes desta ala busca a fantasia na noite do desfile, veste e leva numa sacola ${ }^{15}$ a roupa que vestia. Partem, em grupos, para uma caminhada de trinta minutos até a avenida.

A entrega de fantasias cria uma enorme expectativa entre os componentes, muitas vezes aumentada com os atrasos, costumeiros. Enquanto esperam, comentam passagens dos desfiles dos dias anteriores, quando muitos desfilaram em outras Escolas. A fantasia é recebida com cuidado especial, alguns ritmistas chegam a trazer cabides para transportá-las sem amassar, enqua nto outros, vencidos pela ansiedade, tratam logo de vestí-la, cuidadosamente, num canto da quadra.

As redes de amizade que ligam estes componentes com os das Escolas de Samba dos grupos inferiores, propicia que ela aumente seu número de desfilantes nos momentos que antecedem o desfile ou, de forma mais organizada, anteriormente, com a formação de grupos. A bateria do Acadêmicos da Orgia, por exemplo, teve entre seus componentes, muitos ritmistas da Imperadores do Samba, isto ocorreu devido as relações pessoais entre Mestres de bateria, no caso, pai e filho. Para um determinado carnaval, pode formar-se uma nova ala, "de amigos" do personagem-tema homenageado, são alas especialmente organizadas, geralmente quem dela participa não tem maiores ligações com a Escola mas com a rede de relações do carnavalesco homenageado. Assim foi em 1994, quando a Copacabana desfilou com a ala "Amigos do Pernambuco", entre os quais diversos Imperadores. A mais recente Escola de Samba, "Areal da Baronesa", estreou no carnaval com um tema-enredo sobre o Mestre Neri Caveira, o que determinou a formação da ala "Amigos sempre amigos", composta de familiares e amigos, entre os quais, novamente, diversos Imperadores.

Nos desfiles, a cada noite, as arquibancadas, recebem um número crescente de público, entre eles, rostos conhecidos de Imperadores. Seja desfilando, coordenando, assistindo ou apenas ajudando, eles estão ali. Um dos camarotes, ocupado por Imperadores, só completou seu grupo na noite de segunda-feira, pois nas noites anteriores algumas baianas ficaram em casa terminando de bordar suas fantasias. Os grupos dos camarotes trazem bebidas e alimentos para enfrentar a jornada de mais de dez horas de desfile. O grupo de trabalho, aqueles que de alguma forma estão envolvidos com o desfile da Escola, raramente "visitam" a Pista de Eventos, mas quando o fazem, circulam entre o bar e os camarotes, para saber de alguma novidade importante.

Nos camarotes encontram-se muitos destaques de dança e de carro alegórico e seus familiares. No camarote reúnem-se pessoas conhecidas que planejam antecipadamente assistir

\footnotetext{
${ }^{15}$ Vera fez questão de me mostrar as sacolas plásticas, conseguidas através do seu marido que trabalha em um supermercado.
} 
juntas o desfile. A grande maioria será decorada durante o decorrer do carnaval, para na noite de terça-feira trazer as cores da Escola a qual pertencem. Um mesmo camarote foi dividido ao meio pela decoração, metade vermelho, metade azul, no caso, estava sendo ocupado por uma grande família que tem entre seus membros, Imperadores e bambistas. Apesar de casos como este, geralmente os camarotes são ocupados por grupos nos quais seus membros estão filiados a apenas uma Escola de Samba. Um componente, instalado num camarote, fazia as contas de quantos "camarotes Imperador" haviam em contraposição a "camarotes da Restinga" (e do Bambas).

No barracão a tensão domina o ambiente. Na manhã da terça-feira de carnaval, gravado em giz branco na parede do barracão, a frase chamava a atenção de quem entrava: "É hoje $o$ grande dia”. O barracão estava tomado de Imperadores, colorindo de vermelho o ambiente. Alguns carros alegóricos já estavam na rua em frente, sendo remontados e finalizados os últimos acabamentos, enquanto outros eram retirados cuidadosamente, carregados nos braços. Todos estvam fazendo alguma coisa, carregando, pregando, colando ou empurrando os carros. O grupo que trabalhou no barracão mostrava na face o cansaço e nas vestes e no corpo o descuido pessoal. Coordenavam a saída dos carros, alguma quebra ou estrago nas alegorias seria motivo para explosões emocionais, logo diluídas quando são acionados para solucionar outros problemas no barracão. A saída dos carros alegóricos do barracão tomará todo o dia e início da noite de terça-feira, de forma que quem ali está trabalhando seguirá diretamente para o desfile. Alguns conseguem ir para casa, tomar banho, vestir-se e ir para a avenida. A maioria do grupo de trabalho, entretanto, tomará banho no próprio barracão ou na casa de algum conhecido que more próximo ao local de desfile e seguirá diretamente para a Pista de Eventos.

$\mathrm{Na}$ quadra, a agitação fica por conta das alas e, principalmente, do trabalho de organização dos instrumentos da bateria. Todos os instrumentos serão limpos e azeitados, tratados separadamente, contados e organizados a espera do desfile. Algumas alas ainda esperam componentes que não vieram retirar suas fantasias. O clima é de expectativa e nervosismo. A secretária da bateria, ainda entregava fantasias enquanto bordava o biquini que sua nora iria usar no desfile. Uma componente chegava nervosa em quadra e logo estava cercada por um grupo de conhecidos. Chorava ao contar que estava sem sapato para o desfile, deixou para comprar no último dia e não encontrou. O grupo trata logo de incentivar e ajudar no possível. Alguém tem um sapato para emprestar, outro emprestará a tinta e, um terceiro, se oferecerá para pintá-lo, resolvendo o problema coletivamente.

A espera do horário de desfile é ansiosamente aguardada na área da concentração ou no espaço que a antecede. No meio da madrugada muitos ritmistas já vestiram a fantasia, 
cuidadosos para não sujá-la. A presidente da ala orientava os componentes que cuidassem com as poças de lama de forma que não sujassem a fantasia mas alertava "lá dentro não, na avenida é prá pisar na poça mesmo, tem que ir em frente”. Muitos componentes vestem-se nas áreas circundantes à concentração, o que exige, mvamente, a colaboração de outras pessoas. Ao se vestir na avenida, o componente terá que deixar a roupa que vestia com alguém, criando uma efervescência de interações nos locais próximos ao desfile. São familiares, irmãos, mães, avós, amigos, que ali estão para ajudar o componente a se vestir e guardar seus pertences.

A Escola orienta seus componentes para concentrarem faltando duas horas para o desfile. Os atrasos no entanto são corriqueiros, muitos moram longe, dependem de transporte coletivo e qualquer pequeno atraso pode se transformar em um grande problema. Alda, a secretária da bateria conta como foram seus momentos antes do desfile de 1994. Durante a tarde estava em quadra, no início da noite foi para casa jantar e se vestir, só que encontrou sua filha, segunda Porta-Estandarte, chorando, pois não havia conseguido terminar de fazer a barra da saia da fantasia. Acabou se atrasando, de forma que quando voltou para a quadra para, de ônibus, seguir com a bateria para a avenida, houve desencontro. É Alda que narra esta passagem:

“peguei uma carona e desci prá quadra, já estava saindo todo mundo, aí fiquei prá fechar a salinha, porque ainda havia ficado fantasia, guardar as bolsa dos guri que tinham levado a roupa prá se arrumar lá na quadra, aquelas coisas, os chapéus, chaveei a casinha, aí saímos da quadra, tivemos que pegar um táxi prá ir na avenida. Chegamos na avenida e a maioria já tinha pego seus instrumentos, a bateria já tava montando, fui ajudar a Bianca (sua filha, Porta-Estandarte) a terminar de se arrumar né, botar a roupa ... mas nesse meio tempo todo esquecemos a fantasia da Renata (sua nora, componente da ala perigosas peruas), tivemos que mandar a Maria (amiga e esposa de um ritmista) pegar um táxi e vim buscar e voltar, aí nesse meio tempo todo o Imperador já tá entrando né ... mas deu tempo, a Maria chegou, a gente trocou a roupa dela, fomos as últimas a passar na contagem, o Imperador já tava lá no portão ... aí foi aquele corre-corre, e o coração batendo né, pensando não vai dar tempo prá nós passar, nós não vamos passar...”. 
O momento da concentração é muito tenso, os diretores e o grupo de trabalho correm de um lado a outro, montando a Escola, orientando alas, trazendo os carros alegóricos, resolvendo problemas. Os componentes, por sua vez, estão também muito ansiosos, querendo saber se todos os carros vão desfilar ou se os destaques já chegaram. Um boato, na concentração, anuncia que a Comissão de Frente ainda não chegou deixando os componentes mais nervosos, quando ela passa, atrasada, por entre a alas para se posicionar na frente da Escola, é recebida com gritos e aplausos. Comentam os desfiles do Bambas da Orgia e da Restinga, caso já tenham ocorrido. Se desfilaram bem, o grupo então terá que se superar e desfilar "melhor" ainda, se algum problema aconteceu ficam satisfeitos e se propõe a "fazer a nossa parte".

O momento da concentração traz muita emoção a quem dele participa. O rufar dos tambores anunciando a entrada da bateria, o puxador com seus gritos de guerra, os foguetes ensurdecedores, o nervosismo geral, criam um clima emocional muitas vezes expresso nas lágrimas dos componentes. Nas arquibancadas o clima não é diferente, as torcidas se agitam, gritando muito. O público participa cantando e assistindo, vendo as alegorias, as alas, “a Escola passar”. Percebe-se que algumas pessoas só torcem para a sua Escola, chegando a cruzar os braços para observar as Escolas rivais passarem, entretanto, geralmente o que se vê é a participação geral do público, seja através do canto, dança ou admiração visual. Torcer por uma Escola de Samba é não só "brincar o carnava" mas reafirmar-se enquanto "comunidade", torcer, nesse sentido, reflete a consciência de pertencer a determinado grupo.

As interações entre o público e os componentes no desfile, são também importantes momentos que mostram a rede de relações que se formam através das Escolas de Samba. Como as arquibancadas são de baixa altura, público e componentes estão frente a frente, reconhecendose a todo instante. São amigos e familiares a procura do componente na avenida, são componentes e destaques reconhecendo amigos e familiares na torcida. Da Matta (1973) chama de "gesto típico" do carnaval, quando o componente desfila com os braços levantados e abertos, tentando "abraçar genericamente a todos":

“...abraçam simbolicamente todos os foliões (e por extensão à humanidade) (...) Neste gesto aparentemente simples de conciliação com o mundo há toda uma expressão de alegria e liberdade que a própria posição dos braços demonstra claramente (...) sinal de fraternidade universal”.(Da Matta,1973:138). 
As fantasias, é importante observar, não comportam máscaras, que segundo Turner (1974:208) assegurariam o anonimato Evidencia que o grupo quer mostrar a face de seus componentes, buscando o reconhecimento e não o anonimato.

\section{Comentários finais}

Partindo de um estudo de caso realizado junto ao Grupo Carnavalesco Imperadores do Samba, busquei reconstruir os diversos níveis e domínios do seu cotidiano, revelando sua maneira peculiar de ordenar o tempo, suas redes de relações e a identidade construída, na sua dimensão simbólica e nas redes de relações sociais.

Estudar o carnaval realizado por esta Escola de Samba exigiu reconhecê-la enquanto um grupo inclusivo no qual a sociabilidade é parte integrante do seu cotidiano e revela muito dos valores, modos de pensar e agir dos que dela participam. Estas interações, geradas através da Escola de Samba, produzem significados, delimitam espaços, propiciam a expressão simbólica de suas identidades e de seus conflitos, marcando as diferenças entre "nós" e "eles".

A sociabilidade do grupo oscila entre tempos de grande e pequena interação, mas permanece e se revitaliza nos mais diferentes encontros promovidos ou desfrutados pela Escolas de Samba. Percorrendo um ciclo arnavalesco percebe-se que a sociabilidade é contínua e vivenciada através de várias formas, seja nas ruas, na quadra de ensaios, em clubes ou outros espaços da cidade, agrupam-se através de festas, ensaios, apresentações públicas, churrascos, almoços, bailes, shows ou rodas de samba. Sempre festas, todo o tempo, por toda a parte e por todos os motivos. A ênfase de eventos sociais mostra como festejar é prioritário e indispensável ao grupo. Há uma rotina de festas, previstas e esperadas, que mobilizam os sujeitos do grupo. E as festas, não se pode esquecer, são "marcos importantes para a estruturação do tempo e a ordenação de uma visão da sociedade e do sentido da vida"(Macedo,1986:186).

A percepção de tempo do grupo singulariza-se por não obedecer a uma concepção linear e histórica, típica da ideologia individualizante moderna. O tempo é totalizado e percebido “como um movimento pendular" (Da Matta,1983:22) onde a realidade cotidiana passa a ser ordenada pelo ciclo ritual do carnaval. O ritual, nesse sentido, não só interfere como determina a noção de tempo deste grupo.

Na sequência do ciclo ritual, cada "tempo" situa-se com relação aos outros tendo em vista um fim determinado, o desfile da Escola de Samba. Por trás da multiplicidade de formas que possam apresentar a disposição sequencial é sempre a mesma: carnaval, pós-carnaval, précarnaval, carnaval, ... sucessivamente. 
O pós-carnaval, é o breve período que sucede ao carnaval, representado pelo grupo enquanto férias ou descanso, quando "se pensa mas não se faz o carnaval". É um tempo de relaxamento nas relações sociais antes tão intensificadas pela Escola, que deixa de ser a principal mediadora das relações interpessoais. É um tempo de separação da Escola e reaproximação de outras redes de relações não mediadas pela Escola de Samba.

O pré-carnaval, por sua vez é representado enquanto um tempo de "fazer carnaval", de reagregar Imperadores, e simpatizantes através dos ensaios, festas, almoços, bailes, compondo um tempo de intensa sociabilidade. O pré-carnaval também demarca um momento de intensificação das relações pessoalizadas entre os membros do grupo. De terça-feira à domingo, na quadra, encontram-se componentes, diretores, simpatizantes ou meros frequentadores em busca de diversão. É um tempo de agregação, base sobre a qual constróem a identidade Imperador.

O carnaval surge então como o tempo de “mostrar o que foi feito”, o tempo do ritual é o momento de "reconhecimento" ao trabalho realizado. Lembrando o que Zaluar (1985:186) afirmou: "o samba levanta o moral, limpa o estigma, dignifica e abre caminhos para a realização pessoal dos trabalhadores pobres", observourse que a Escola de Samba possibilita, entre as pessoas que dela participam, a construção de uma auto-imagem positiva. Se a sociedade mais ampla os negativiza enquanto pobres, marginais, negros, suburbanos, etc, estas mesmas pessoas, através da Escola, são valorizadas enquanto “artistas”, e campeões.

A continuidade temporal, portanto, é percebida através de uma temporalidade cíclica (carnaval, pós-carnaval e pré-carnaval), A memória coletiva aparece como uma referência importante para a atualização da identidade do grupo, pois através dela o tempo carnavalesco vivido é ordenado. Nestas reordenações temporais o carnaval é sempre referência para delimitar o tempo vivido (“carnaval do Gandhi”, “o ano do falcão”, “o ano do Povo Meu”).

\section{Referências}

BAKHTIN, Mikhail. A cultura popular na idade média e no renascimento. São Paulo: EDUNB, 1993.

BERGER, Peter, LUCKMANN, Thomas. A construção social da realidade. Petrópolis: Vozes, 1985.

BITTENCOURT JÚNIOR, Iosvaldir C. Relógios da noite: uma antropologia da territorialidade e da identidade negra em Porto Alegre. Porto Alegre: PPG Antropologia Social/UFRGS, 1995. (Dissertação de Mestrado). 
BORELLI, Sílvia H. S. Memória e temporalidade: diálogo entre Walter Benjamin e Henri Bergson. Margen. São Paulo, n. 1, p. 79-90, 1992.

BOSI, Ecléa. Memória e sociedade. São Paulo: EDUSP, 1987.

CAILLOIS, Roger. Os jogos e os homens. Lisboa: Ed. Cotovia, 1990.

CAVALCANTI, Maria Laura V. de C. Onde a cidade se encontra: o desfile das escolas de samba no Rio de Janeiro. Rio de Janeiro: Museu Nacional/UFRJ, 1993. (Tese de Doutorado).

DA MATTA, Roberto. A casa e a rua. São Paulo: Brasiliense, 1985.

. Carnavais, malandros e heróis. Rio de Janeiro: Zahar, 1983.

. "O Carnaval como rito de passagem". In: Ensaios de antropologia estrutural. Petrópolis: Vozes, 1973. p. 121-168.

ECKERT, Cornélia. "Memória e identidade". Cadernos de Antropologia, PPG Antropologia Social/UFRGS, Porto Alegre, n. 11, p. 9-84, 1993.

GUTERRES, Liliane S. “Sou Imperador até morrer”. Um estudo sobre identidade, tempo e sociabilidade em uma Escola de Samba de Porto Alegre. Porto Alegre: PPG Antropologia Social/UFRGS, 1995. (Dissertação de Mestrado).

GEERTZ, Clifford. A Interpretação das culturas. Rio de Janeiro: Guanabara, 1989.

GOLDWASSER, Maria Júlia. O palácio do samba. Rio de Janeiro: Zahar, 1975.

HALBWACHS, Maurice. A memória coletiva. São Paulo: Vértice, 1990.

LEOPOLDI, José Sávio. Escola de samba, ritual e sociedade. Petrópolis: Vozes, 1978.

LÉVI-STRAUSS, C. O pensamento selvagem. São Paulo: Companhia Editora Nacional, 1976.

MACEDO, Carmen Cinira. Tempo de gênesis. São Paulo: Brasiliense, 1986.

MAUSS, Marcel. Uma categoria do espírito humano: a noção de pessoa, a noção de eu. In: Sociologia e antropologia. São Paulo: EPU/EDUSP, 1974.

MORAES FILHO, Evaristo de. (Org.). Simmel. São Paulo: Ática, 1983. (Coleção Grandes Cientistas Sociais, v. 34).

OLIVEIRA, Roberto Cardoso de. (org.) Marcel Mauss - antropologia. São Paulo: Ática, 1979. (Grandes Cientistas Sociais; 11).

OLIVEN, Ruben G. A parte e o todo. Petrópolis: Vozes, 1992. 
ORTIZ, Renato. A consciência fragmentada. Rio de Janeiro: Paz e Terra, 1980.

PEROSA, Angelo J. Carnaval: O Potlatch da Sociedade Complexa no Brasil. Cadernos de Campo, n.3. 1993

QUEIROZ, Maria Isaura P. A ordem carnavalesca. Tempo Social, São Paulo, 6(1-2): 27-45, 1995.

RADCLIFFE-BROWN, Alfred R. Estrutura e função na sociedade primitiva. Petrópolis: Vozes, 1973.

SILVA, Josiane A. da. Bambas da Orgia: um estudo sobre o carnaval de rua de Porto Alegre, seus carnavalescos e os territótios negros. Porto Alegre: PPG Antropologia Social/UFRGS, 1993. (Dissertação de Mestrado).

SIMMEL, G. Sociologia. Organizador Evaristo de MORAES FILHO. São Paulo: Ática, 1983.

TURNER, Victor W. O processo ritual: estrutura e antiestrutura. Petrópolis: Vozes, 1974.

VAN GENNEP, Arnold. Os ritos de passagem. Petrópolis: Vozes, 1978.

VELHO, Gilberto.Individualismo e cultura. Rio de Janeiro: Zahar, 1981. . Subjetividade e sociedade. Rio de Janeiro: Zahar, 1986.

VIANNA JR,Hermano. O mundo funk carioca. RJ: Jorge Zahar, 1988.

WAGNER, Helmut R. (org.). Fenomenologia e Relações Sociais. Textos Escolhidos de Alfred Schutz. Rio de Janeiro, Zahar, 1979.

ZALUAR, Alba. A máquina e a revolta. São Paulo: Brasiliense, 1985. 